\title{
Makna Pesan dalam Tari Tradisional (Analisis Deskriptif Kualitatif Makna Pesan dalam Kesenian Tari Piring)
}

\author{
Siti Fathonah, Sinta Paramita, Lusia Savitri Setyo Utami. \\ siti.915150065@stu.untar.ac.id,sintap@fikom.untar.ac.id,lusias@fikom.untar.ac.id
}

Fakultas Ilmu Komunikasi Universitas Tarumanagara

\begin{abstract}
The author conducted this study aims to find out about the meaning of the message contained in each of the movements shown by the dancer and the meaning of the message to be conveyed in the art of Tari Piring. The research method used by the author is a case study method, using a qualitative descriptive approach. And data collection is done by using observation, interview, documentation, and literature studies. The subjects in this study were the Solok people who were domiciled in Jakarta namely, the Minangkabau Tourism Ambassador, the Director of Sanggar Syofyani, the Trainers or Dancers who were active, and the Solok people who knew about dance arts. the results obtained in the study are movements on Tari Piring art as a result of adaptation from the activities of the Minangkabau community at that time as farmers and fighter, and the meaning of the message to be shown in Tari Piring art is characteristic of the Minangkabau community itself, mutual cooperation hard work, togetherness, and courage. As well as the plate properties used symbolize prosperity and prosperity. The clothes used in Tari Piring Art symbolize the identity of the Minangkabau people who uphold the values of adab, as well as Islamic religious law.
\end{abstract}

Keywords : Culture, Tari Piring, Meaning

\begin{abstract}
Abstrak
Penelitian ini ditujukan untuk mengetahui tentang makna pesan yang terdapat pada setiap gerakan yang ditunjukkan oleh penari serta makna pesan yang ingin disampaikan dalam kesenian Tari Piring. Metode penelitian yang digunakan adalah studi kasus dengan menggunakan pendekatan deskriptif kualitatif. Pengumpulan data dengan menggunakan teknik observasi, wawancara, dokumentasi, dan studi pustaka. Subjek dalam penelitian ini adalah masyarakat Solok yang berdomisili di Jakarta yakni, Duta Pariwisata Minangkabau, Director Sanggar Syofyani, pelatih atau penari yang berstatus aktif, serta masyarakat Solok yang mengetahui kesenian tari piring. Hasil yang didapat dalam penelitian yaitu gerakangerakan pada kesenian Tari Piring merupakan hasil adaptasi dari kegiatan masyarakat Minangkabau pada saat itu sebagai petani dan pesilat, serta makna pesan yang ingin ditunjukkan pada kesenian Tari Piring adalah karakteristik dari masyarakat Minangkabau sendiri yakni sifat gotong royong, bekerja keras, kebersamaan, dan keberanian. Properti piring yang digunakan melambangkan suatu kesejaheraan dan kemakmuran. Pakaian yang digunakan dalam Kesenian Tari Piring melambangkan suatu jati diri masyarakat Minangkabau yang menjunjung tinggi nilai adab, serta syariat agama islam.
\end{abstract}

Kata kunci : Budaya, Tari Piring, Makna 


\section{Pendahuluan}

Kebudayaan merupakan salah satu hal yang tidak bisa dilepaskan dalam kehidupan masyarakat. Adanya kaitan yang begitu besar antara kebudayaan dan masyarakat menjadikan kebudayaan tersebut sebagai suatu hal yang sangat penting bagi manusia di mana masyarakat tidak dapat meninggalkan suatu budaya yang sudah dimilikinya. Kebudayaan adalah kompleks yang mencakup pengetahuan, kepercayaan, kesenian, adat dan kebiasaan-kebiasaan yang dilakukan oleh sekumpulan anggota masyarakat (Soerjono, 2009:150-151). Keseluruhan pengetahuan manusia sebagai makhluk sosial yang digunakan untuk memahami lingkungan serta pengalamannya dan menjadi pedoman tingkah lakunya. Salah satu kebudayaan yang memiliki daya tarik tersendiri di lingkungan masyarakat adalah kesenian tari. Menurut Resi Septiana Dewi dalam buku berjudul Keanekaragaman Seni Tari Nusantara, "seni tari adalah hasil karya cipta manusia yang diungkapkan melalui media gerak yang memiliki keindahan" (2012:01). Salah satu seni tari yang kaya akan makna adalah seni Tari Piring Solok khas Minangkabau.

Tari merupakan suatu media ekspresi ataupun sebagai sarana komunikasi seorang seniman yang ingin ditampilkan kepada penonton maupun penikmatnya. Melalui tarian dapat menunjukan suatu jati diri dari daerah itu tersendiri. Setiap gerakan yang ditampilkan memiliki makna dan filosofi yang kuat, sehingga dapat membuat penikmatnya peka terhadap sesuatu yang ada dan yang terjadi di sekitarnya. Salah satunya adalah tari piring.

Kota Padang yang lebih bertepatan di Solok, Sumatera Barat, merupakan kota yang melahirkan tarian adat tersebut. Tarian khas Minangkabau tersebut menggunakan piring sebagai properti utama dalam kesenian tersebut. Tarian ini biasanya ditampilkan sebagai sarana hiburan, meskipun tak jarang juga menjadi pembuka dalam acara yang dihadiri oleh para tokoh-tokoh besar Minang. Biasanya untuk menarik perhatian penonton, tari ini dimainkan oleh perempuan, maupun lakilaki dan perempuan berpasangan dengan kostum yang berwarna merah sebagai salah satu ciri daerah minangkabau. Awalnya, tari piring hanya dilakukan untuk musim panen. Ritual ini dilakukan bertujuan untuk memberikan rasa syukur terimakasih atas musim panen yang datang dengan melimpah.

Pada tahap awal prosesi ritual biasanya diawali dengan pemberian sesajian untuk dewa-dewa padi atau roh-roh dan penari akan berjalan bersama-sama dengan membawa dulang serta piring yang telah berisikan sesaji makanan atau yang biasa di sebut dengan persembahan. Setelah agama Islam masuk ke Minangkabau, ritual tersebut dilakukan sesuai dengan ketentuan syariat agama, segala bentuk ritual persembahan dan sesajian yang dilakukan pada saat itu kini telah dihapuskan. Hingga saat ini Tari Piring murni hanya sebagai bentuk kesenian dari kebudayaan khas Minangkabau.

Pada dasarnya, suatu tarian yang ditampilkan memiliki makna dan filosofi yang kuat dari setiap gerakannya. Gerakan Tari Piring yang ditampilkan diadaptasi dari keseharian masyarakat Minangkabau yang bekerja sebagai petani saat sedang melakukan proses bertanam di sawah. Pada umumnya, Tari Piring menceritakan mengenai proses bercocok tanam padi. Selain itu, digambarkan pula bagaimana para petani mempelajari seni pencak silat atau yang biasa dikenal oleh masyarakat kota padang adalah Silek Minangkabau. Para penari menampilkan berbagai gerakan tersebut sambil tidak berhenti memainkan piring pada kedua tangannya. Tidak bisa dipungkiri bahwa daya tarik utama dari tarian piring ini adalah aksi akrobatik yang 
dipertunjukan oleh para penari laki-laki. Keterampilan dalam memainkan piring menjadi salah satu sumber estetika tersendiri dari sebuah tari piring. (sumber : wonderful minangkabau https://www.wonderfulminangkabau.com/tari-piring/ diakses pada hari Jumat tanggal 1 Februari 2019.)

Berdasarkan observasi awal, penulis menemukan bahwa kesenian Tari Piring merupakan salah satu kesenian Minangkabau yang hanya menggunakan properti piring sebagai media utama dalam tarian tersebut. Hal tersebut dikatakan oleh Soni Destriana Mentari yang merupakan masyarakat asli Solok yang saat ini sebagai menjabat sebagai Direktur Sanggar Syofyani mengatakan bahwa kesenian tari Minangkabau yang menggunakan media piring hanyalah kesenian Tari Piring, hal tersebut memiliki alasan bahwa hanya kesenian Tari Piring yang merupakan kesenian Minangkabau yang menceritakan rasa syukur masyarakat Minangkabau kepada Tuhan Yang Maha Esa dengan menggunakan piring sebagai simbolnya.

Berdasarkan penjelasan di atas, maka rumusan masalah yakni bagaimana makna pesan dalam kesenian Tari Piring, serta tujuan yang ingin dicapai oleh penulis dalam penelitian ini adalah untuk dapat mengetahui makna pesan dalam tari piring, dan makna pesan yang terkandung pada gerakan-gerakan penari dalam tari piring Berdasarkan penjelasan diatas, penulis berharap adanya manfaat akademis serta praktis yang dapat diambil dari penelitian ini, serta menjadi refrensi untuk peneliti selanjutnya.

Kebudayaan adalah kompleks yang mencakup pengetahuan, kepercayaan, kesenian, adat dan kebiasaan-kebiasaan yang dilakukan oleh sekumpulan anggota masyarakat (Soerjono, 2009:150-151). Komunikasi non verbal adalah komunikasi yang menggunakan isyarat bukan kata-kata (Mulyana, 2010:343). Menurut Samovar komunikasi non verbal mencakup semua rangsangan (kecuali rangsangan verbal) dalam suatu setting komunikasi, yang dihasilkan oleh individu dan penggunaan dilingkungan oleh individu, yang mempunyai nilai pesan potensi bagi pengirim atau penerima. (Riwandi, 2009:69).

Mead mengukuhkan teori interaksi simbolik sebagai suatu kajian tentang berbagai aspek subjektif manusia dalam kehidupan sosial (Kuswarno, 2009:113). Interaksi simbolik adalah segala hal yang saling berhubungan dengan pembentukan makna dari suatu benda atau simbol, baik benda mati mapun benda hidup, melalui proses komunikasi baik sebagai pesan verbal maupun non verbal dan tujuan akhirnya adalah memaknai lambang atau simbol (objek) berdasarkan kesepakatan bersama yang berlaku di wilayah atau kelompok komunitas masyarakat tertentu (Vivi, 2016:8).

\section{Metode Penelitian}

Dalam penelitian ini, penulis menggunakan pendekatan deskriptif kualitatif, serta model yang penulis gunakan adalah studi kasus. Menurut Robert K. Yin, metode studi kasus sebagai keperluan empirik yang menginvestigasi fenomena kontemporer dalam konteks kehidupan nyata, saat pemisah antara fenomena dan konteks tidak didapatkan serta dalam kasus tertentu beberapa sumber dapat digunakan (Husain. 2011:205).

Teknik pengumpulan data yang digunakan yaitu observasi non-participan, wawancara, studi kepustakaan dan dokumentasi. Teknik analisis data yang digunakan adalah teknik analisis kualitatif yang dikemukakan oleh Miles dan Huberman. Objek dari penelitian ini adalah makna pesan pada kesenian Tari Piring, 
sementara subjeknya adalah Pelatih/Penari tari piring yang berstatus aktif yang merupakan masyarakat asli Solok dan mengerti mengenai kesenian tari piring. Duta Pariwisata Minangkabau yang memiliki pemahaman mengenai kebudayaan serta kesenian Tari Piring. Lalu, pemilik Sanggar Tari Piring untuk mendapatkan informasi lebih mendalam mengenai kesenian tari piring serta kebudayaan Minang. Terakhir adalah masyarakat Solok yang mengetahui tentang Tari Piring.

\section{Hasil Temuan dan Diskusi}

\section{a. Makna Gerakan Tari Piring}

Menurut Blumer, teori interaksionisme simbolik bertumpu pada tiga premis yakni manusia bertindak terhadap sesuatu berdasarkan makna-makna yang ada bagi mereka. Makna tersebut diperoleh dari hasil suatu interaksi sosial yang telah dilakukan bersama orang lain. Makna-makna tersebut disempurnakan pada saat proses interaksi sosial sedang berlangsung (Sobur, 2013:199) Karakteristik masyarakat Minangkabau merupakan salah satu makna utama dari kesenian tari piring. Gerakan-gerakan yang ditampilkan diadaptasi dari kegiatan masyarakat Minangkabau yang pada zaman dulu mayoritas berprofesi sebagai petani dan pesilat. Makna-makna tersebut terbentuk dari suatu interaksi sosial masyarakat Minangkabau dan disempurnakan ketika interaksi sosial tersebut berlangsung.

Dari hasil analisis dengan menggunakan teori interaksionisme simbolik terungkap makna yang terkandung dalam setiap gerakan-gerakan pada kesenian Tari Piring. Gerakan-gerakan yang ditampilkan dari Tari Piring bukan hanya diadaptasi dari kegiatan masyarakat Minangkabau yang pada zaman dulu berprofesi sebagai petani, namun juga diangkat dari beberapa gerakan-gerakan silat. Gerakan-gerakan yang dimaksud tersebut antara lain, Gerak Pasambahan yakni gerakan yang memiliki makna untuk sembah syukur kepada Allah SWT, Gerak Singanjuo Lalai yakni gerakan yang memberi makna pesan yaitu sebagai manusia jika ingin mendapatkan suatu rezeki yang baik maka awali hari dengan selalu bekerja keras, Gerak Mencangkua memberikan makna pesan bahwa sebagai manusia jika ingin mendapatkan sesuatu maka harus diiringi doa dan usaha yang keras, Gerak Mengantar Juadah memiliki makna pesan bahwa dalam suatu kehidupan harus mempererat sifat kebersamaan satu sama lain, Gerak Gotong-Royong merupakan lambang serta memiliki makna pesan akan sifat saling bergotong-royong satu sama lain pada masyarakat Minangkabau, Gerak Injiak Piriang yakni makna yang ingin ditunjukkan adalah "keberanian" bahwa masyarakat Minangkabau merupakan masyarakat yang berani serta demokratis dan masyarakat Minangkabau merupakan orang yang bisa diandalkan.

\section{b. Makna Busana pada Tari Piring}

Mead mengatakan bahwa makna ada sebagai hasil interaksi di antara manusia, baik itu secara verbal ataupun nonverbal. Melalui aksi dan respon yang terjadi, kita memberikan makna ke dalam bentuk kata-kata atau tindakan, dan karenanya kita dapat memahami suatu peristiwa dengan cara-cara tertentu (Morrisan, 2013:74). Pakaian merupakan suatu cerminan diri dari seseorang, dengan melihat pakaian seseorang, maka akan menimbulkan suatu pandangan dari orang lain. Sekaligus cerminan pakaian menunjukkan bangsa. Maka pakaian adat dapat mewakili masyarakat dan adat sesuatu daerah yang membedakannya dengan adat daerah lain. Pakaian adat pada Tari Piring memiliki peranan penting sebagai identitas diri dari 
kebudayaan tersebut. Makna yang terdapat pada busana yang digunakan oleh penari kesenian Tari Piring merupakan suatu hasil dari interaksi sosial masyarakat Minangkabau. Pakaian yang digunakan mengandung makna yang sesuai dengan norma-norma Islam. Bukan hanya semata menganggap pakaian berfungsi untuk menutup tubuh saja, melainkan menutup aurat dan untuk keindahan. Dari situ terlihat bahwa makna yang ingin ditunjukkan dari busana yang digunakan penari Tari Piring adalah karakteristik masyarakat Minangkabau yang agamis, demokratis dan berpendirian teguh.

\section{c. Makna Properti Tari Piring}

Properti piring yang digunakan pada kesenian Tari Piring memiliki makna dan nilai sejarah tersendiri. Mead mengatakan bahwa makna muncul sebagai hasil interaksi di antara manusia, baik secara verbal ataupun nonverbal. (Morrisan, 2013:74). Makna dari piring merupakan lambang dari kemakmuran dan kesejahteraan bagi masyarakat Minangkabau. Sampai saat ini Tari Piring masih sering ditampilkan pada acara kebesaran atau acara adat tertentu seperti pesta rakyat baralek (merupakan pernikahan adat khas minangkabau) dan batagak penghulu (penaikan penghulu). Tidak hanya itu, bahwa Tari Piring juga memiliki sebuah harapan agar pengantin selalu diberikan kelimpahan rezeki.

\section{Simpulan}

Makna pesan dalam Tari Piring adalah menjunjung tinggi nilai adab, agama, kebersamaan, gotong royong, bekerja keras, demokratis dan keberanian yang merupakan karakteristik dari masyarakat Minangkabau. Makna tersebut ditanamkan kepada seluruh generasi guna dapat memahami dan mengamalkan nilai-nilai tersebut. Makna yang ingin diungkapkan pada kesenian Tari Piring ini juga merupakan cerminan dari corak budaya dalam artian nilai yang menjadi tingkah laku di Minangkabau.

\section{Ucapan Terima Kasih}

Penelitian ini penulis persembahkan kepada kedua orang tua serta pembimbing utama ibu Sinta Paramita, SIP., MA, dan Co-Pembimbing ibu Lusia Savitri Setyo Utami, S.Sos., M.Si., yang telah membantu penulis memberikan arahan dalam menyusun penelitian ini, serta kerabat di Universitas Tarumanagara dan para informan yang telah memberikan informasi mengenai penelitian ini.

\section{Daftar Pustaka}

Aprilia, Vivi. (2016). Makna simbolik komunikasi budaya dalam upacara adat perkawinan masyarakat batak toba di pekanbaru. Jurusan ilmu komunikasi hubungan masyarakat fakultas ilmu sosial dan ilmu politik. Universitas Riau. JOM FISIP vol 3 no 2 oktober 2016

Dewi, Resi Septiana. (2012). Keanekaragaman Seni Tari Nusantara. Jakarta: PT. Balai Pustaka

https://www.wonderfulminangkabau.com/tari-piring/

Jurnal Ekspresi Seni. Vol 17. No. 1 Juni 2015 
Kuswarno, Engkus. (2009). Fenomenologi: Metodelogi Penelitian Komunikasi. Bandung: Widya Padjajaran

Morissan. (2013). Teori komunikasi : individu hingga massa . Jakarta : Kencana.

Mulyana, Deddy. (2010). Ilmu Komunikasi Suatu Pengantar. Bandung: PT. Remaja Rosdakarya

Riswandi, (2009). Ilmu Komunikasi (cetakan Pertama). Yogyakarta : Graha Ilmu Sobur, Alex. (2013). Semiotika Komunikasi. Bandung: PT. Remaja Rosdakarya, Soerjono, Soekanto. (2009). Sosiologi suatu Pengantar. Jakarta; Rajawali Pers 